\title{
NATALIA FERNÁNDEZ DE CASTRO ES LUIS DE VIANA: UNA CORRESPONSAL GADITANA EN LA PRENSA MEJICANA
}

\author{
Ma del Carmen Cózar Navarro \\ Universidad de CÁdiz
}

\section{RESUMEN}

Este trabajo tiene por objeto dar a conocer la labor literaria que Natalia Fernández de Castro y Bustamante, miembro de una de las más importantes familias de la ilustrada burguesía de negocios del Cádiz isabelino, desarrolló como corresponsal de la prensa mejicana en el último tercio del siglo XIX. En la misma línea que otras escritoras de su época adoptará un rol masculino, Luis de Viana, tras el que se ocultará "una mujer culta capaz de mantener una actividad literaria y manifestar una opinión política sobre los acontecimientos en curso".

PALABRAS CLAVE: Burguesía, corresponsal, prensa, Méjico, rol masculino.

\section{ABSTRACT}

This work aims to raise awareness of the literary work that Natalia Fernandez de Castro and Bustamante, a member of one of the most important families of the enlightened bourgeoisie business of Cádiz isabelino, developed as a correspondent of the mexican press within the last third of the nineteenth century. In the same line that other writers of his time adopt a masculine role, Luis de Viana, after which will hide "a woman cultured capable of maintaining a literary activity and to express a political oppinion about time’s current facts”.

KEY WORDS: Bourgeoise, correspondent, press, mexican, masculine role. 


\section{Introducción}

Este trabajo tiene por objeto dar a conocer la labor que Natalia Fernández de Castro y Bustamante, miembro de una de las más importantes familias de la ilustrada burguesía de negocios del Cádiz isabelino, desarrolló como corresponsal de la prensa mejicana en el último tercio del siglo XIX. El tema suscita gran interés ya que a través de él podemos conocer el papel que la prensa desempeñó en los años que siguieron a la emancipación como vínculo social y cultural entre la vieja metrópoli, España, y la naciente nación mejicana. Pero, más allá de esta primera valoración historiográfica, el hecho de que tras el nombre del corresponsal Luis de Viana se oculte una mujer casada, hija de una familia tan tradicional como la suya, me ha parecido particularmente sugestivo por cuanto puede aportar a la historia contemporánea del periodismo y de las mujeres.

Evidentemente, Natalia no fue pionera como corresponsal de prensa. Antes que ella otras españolas escribían en los periódicos ${ }^{1}$ y algunas, entre las que cabe señalar a Margarita Pérez de Celis, y a Josefa Zapata incluso crearon y dirigieron, precisamente en Cádiz, publicaciones de corte feminista como ” El pénsil gaditano” y "El pénsil de Iberia”2.

Propugna Natalia el hermanamiento entre las sociedades, española y mejicana, que por su ascendencia, respectivamente paterna y materna, tan bien conoce, mostrando a través de sus cartas una cercanía que el distanciamiento político no pudo borrar. Pero lo que en ella resulta realmente llamativo es que el rigor de sus opiniones, propio de un espíritu femenino independiente, se revista de una identidad masculina para hacerlo así compatible con los valores conservadores que su circunstancia familiar y social le imponía.

Hay que tener en cuenta que a finales de la centuria el 90 por ciento de la población española era analfabeta y que estos porcentajes se elevan en el caso femenino. El horizonte intelectual de la mujer no era amplio ya que su función en la sociedad era la de esposa y madre. En este contexto, Natalia se destaca, al manifestarse como una mujer cultivada, con una notable formación literaria y musical como podemos advertir al leer sus artículos. Pese a ello, no transgrede la norma conservadora de mantenerse dentro del orden establecido ${ }^{3}$, ocultando su feminidad, limitándose a informar y hacer una valoración de la noticia ${ }^{4}$.

Ella no reivindica la igualdad de derechos entre el hombre y la mujer. En sus escritos, como periodista, adoptará el rol masculino, se metarfosea de masculinidad, y

\footnotetext{
1 Son más de trescientas las mujeres andaluzas que colaboraron en la prensa del siglo XIX, sus nombres se repiten en las publicaciones de las distintas revistas. Eran más escritoras que periodistas, aunque algunas sólo escribieran en la prensa. Son bastantes las que nos sorprenden por la cantidad y la variedad de sus creaciones. Muchas alcanzaron la fama en su tiempo y parece inexplicable el olvido en el que están sepultadas. CARMONA GONZÁLEZ, Ángeles: Escritoras andaluzas en la prensa de Andalucía del siglo XIX., Universidad de Cádiz, 1999, pp. 9-34.

2 Antología de la prensa periódica isabelina escrita por mujeres (1843-1894). Edición de Iñigo Sánchez Llama, Cádiz: Universidad de Cádiz, 2001.

3 CARMONA GONZÁLEZ, Ángeles: op.cit.

4 SIMÓN PALMER, Ma ${ }^{a}$ del Carmen: "La mujer y la literatura en la España del siglo XIX.” Actas VII., Centro virtual Cervantes, 1983.
} 
como tal se dirige a un público, sus lectores, formado en un porcentaje muy elevado por varones, porque en Méjico la consideración de la mujer era la misma que en España, el porcentaje de analfabetismo en el ámbito femenino era muy elevado ${ }^{5}$ y todavía esta profesión, como casi todas, era terreno de dominio masculino ${ }^{6}$. No trata Natalia de cambiar las cosas y, desde su fingida posición varonil nos trasmite su convicción de que el destino de la mujer no es otro que la suprema misión de esposa y madre. En este sentido, desde su posición masculina, como si de un hombre se tratase, nos transmite su convicción de que el destino de la mujer no es otro que el cumplimiento de la suprema misión de esposa y madre. Así, considera que la mujer debe tener

"un papel subordinado en la sociedad doméstico patriarcal en virtud de las leyes naturales y divinas" 7

¿Es Natalia un tipo de mujer propio de su tiempo? O más allá de esta cuestión ¿Cuál era la verdadera Natalia? Trataremos de contestar a estas preguntas en las páginas siguientes.

\section{Natalia Fernández de Castro: la mujer}

Natalia nace en Santander, en 1834, sexta hija del matrimonio formado por Ignacio Fernández de Castro y Concepción de Bustamante y Padilla. Su padre era vástago de una familia de la villa cántabra de Comillas, con viejo estatuto de hidalguía y por tradición dedicada a la navegación y al comercio de ultramar. Su actividad mercantil, al comienzo de su carrera, le había llevado a establecerse temporalmente en Nueva España, donde conoció a Concepción de Bustamante y Padilla, con la que contrajo matrimonio en la villa mejicana de Piti, perteneciente al departamento de Sonora, en 1819. Dedicado a los mercados asiáticos, entre Nueva España y Filipinas, al producirse la independencia del virreinato se vio obligado a abandonarlo y a afincarse definitivamente en Cádiz para, desde esta ciudad, continuar el tráfico con Manila. Con tal finalidad, estableció una próspera casa de comercio, que participaría en la Carrera de Manila mediante la construcción y explotación de clippers de gran porte. Esta actividad duró hasta que el Canal de Suez, que hizo económicamente rentable la navegación a vapor en las líneas de Extremo Oriente, puso fin a la hegemonía de los grandes veleros ${ }^{8}$.

Natalia tenía 11 años cuando llegó, con su familia, a Cádiz, ciudad que se vanagloriaba de ser la más cosmopolita de la nación. Con toda probabilidad, adquirió su formación y su cultura en el ambiente familiar. En esta época, la instrucción de las mujeres se consideraba un asunto privado y, por ello, solían educarse en sus casas, mientras esperaban un matrimonio adecuado. No nos cabe la menor duda, sin embargo, que también tuvo que influir en su formación la intensa actividad cultural que había en

5 JIMÉNEZ MORELL, Inmaculada: La prensa femenina en España desde sus orígenes a 1868. Madrid, ediciones de la Torre, 1992, p. 31.

6 SALGUERO BÁEZ, Rosa Lili: De sabinas, Coahuila, al corazón del país. María Rios cárdenas periodista feminista en tiempos posrevolucionarios. Universidad nacional Autónoma de México. pp. 3 y ss.

7 JIMÉNEZ MORELL, Inmaculada: op. cit. p. 44.

8 CÓZAR NAVARRO. Ma del Carmen: Ignacio Fernández de Castro, una empresa naviera gaditana, Cádiz, Servicio de Publicaciones, 1998. 
Cádiz en la etapa isabelina, un ambiente intelectual en el que la mujer gaditana tuvo participación activa, como nos narra Benito Pérez Galdós cuando, en sus Episodios Nacionales, se refiere a la urbe gaditana.

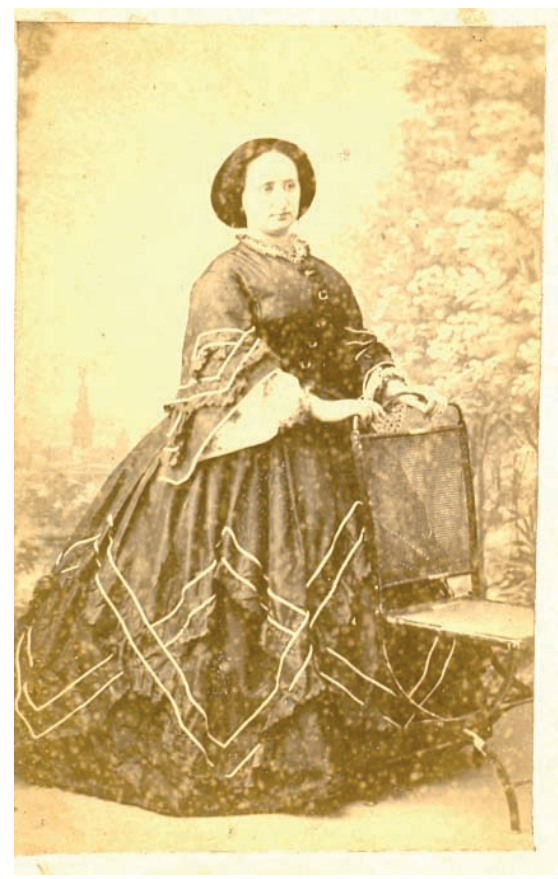

Natalia Fernández de Castro

Como se sabe, era frecuente en Cádiz que las mujeres, marginadas de los centros intelectuales ${ }^{9}$ por su condición femenina, organizasen, ya desde los inicios de la centuria decimonónica, tertulias como fueron la de Margarita López de Morla, de tendencia liberal, y la de $\mathrm{D}^{\mathrm{a}}$ Frasquita Larrea ${ }^{10}$, de carácter conservador, ambas muy conocidas y hasta famosas en la provincia gaditana.

Este ambiente debió influir mucho en la formación de Natalia como escritora. De hecho, tenemos constancia de su admiración por Cecilia Böhl de Faber ${ }^{11}$, hija de

9 La segunda ciudad en fundar un ateneo fue Cádiz en 1858, tras la disolución del Liceo Gaditano, y curiosamente en la Constitución de 1845, vigente en ese momento, no se recogen los derechos de reunión, asociación y expresión. El protagonismo de las mujeres en los ateneos fue prácticamente inexistente. En AGUDO LÓPEZ, Teresa:”el ateneo y las mujeres ante el siglo XXI. Conferencia impartida en el Ateneo de Cádiz. Soporte electrónico.

10 Francisca Javiera Ruiz de Larrea y Aherán - Frasquita Larrea, como se la conocía popularmente- que tradujo a lord Byron. Ella fue una de las introductoras de las ideas románticas en España, y le debemos, igualmente, las primeras traducciones de la obra de Mary Wollstonecraft, autora de "Vindicación de los derechos de la mujer”. ESPIGADO TOCINO, Ma Gloria y DE LA PASCUA SÁNCHEZ, Ma José. Frasquita Larrea y Aherán: europeas y españolas en la ilustración y el Romanticismo. Cádiz, 2003.

11 CANTOS CASENAVE, Marieta (1996): “Fernán Caballero y el mundo vitivinícola andaluz” en RAMOS SANTANA, Alberto y MALDONADO ROSSO (eds) : Ej. jerez.- xérés-sherry en los tres últimos siglos. El Puerto de Santa María, 1996. 
Frasquita Larrea, que empezaba a despuntar como escritora despertando la admiración de Natalia, quien leía con avidez los periódicos “La Bética”, “La España literaria” y "El Heraldo de Madrid”, en los que la novel escritora solía publicar sus escritos bajo el seudónimo de Fernán Caballero.

De esta manera, Natalia, se refiere a la que sería una de las grandes escritoras románticas de la centuria decimonónica:

"Una distinguida escritora andaluza cuyas obras dan a conocer en cada una de sus páginas a más de un elevado talento un alma hermosa y un tiernísimo corazón...”12.

Natalia se nos aparece como una mujer poco común entre las de su clase. Cuando, a sus 22 años, contrae matrimonio, lo hace, no con un comerciante como era habitual en el mundo de los negocios, sino con un Comandante de Caballería de 31 años, por entonces destinado en Zaragoza aunque de familia también radicada en Comillas, Miguel de la Torre de Trasierra. La ceremonia religiosa, se celebró el 1 de febrero de 1856 en la gaditana Iglesia de Nuestra Señora del Rosario ${ }^{13}$ y tuvo carácter secreto, tal como se refleja en la documentación. No hemos podido averiguar las causas por las que se adoptó esta forma canónica pero, habida cuenta de la relación de paisanaje entre las familias de ambos contrayentes, no cabe descartar la existencia de motivos económicos para mantener oculto el enlace.

El joven matrimonio se trasladó a Madrid, ciudad en la que fijarán su residencia familiar, en la calle Santa Clara, número 2. Cuando, el 30 de noviembre $1856^{14}$ nace el primer hijo del matrimonio, Gonzalo, Miguel, su padre, se encontraba en Sevilla como Ayudante de Campo del Teniente General D. Fernando Norzagaray, Capitán General de Andalucía, plaza en la que permanecerá hasta que, a primeros del año siguiente, se incorpore al Ejército de Filipinas, al que fue destinado. Natalia no le acompañaría y, ante estas circunstancias, no sabemos si regresaría a Cádiz con sus padres o si, tal vez, se quedaría con su familia política en Comillas. Regresado Miguel en $1860^{15}$, el matrimonio estableció su residencia en Madrid.

A estas alturas de mi investigación, pues, me preguntaba de dónde se sentía realmente Natalia, de Comillas, de Cádiz o de Madrid. El solar cántabro de su familia y la luz gaditana de su infancia y juventud debieron ejercer poderosa influencia en su personalidad, pero, tal vez por sus años de permanencia en la Corte, o por su carácter inquieto y sociable, Natalia debió sentirse madrileña, sabor que nos deja la lectura de la prosa que nos ha legado.

Pero, sin que ello desdibuje esta imagen de la autora, ciertamente sus cartas también manifiestan un hondo sentimiento de nostalgia por Comillas y, a la vez, un gran amor por Andalucía, de lo que nos viene a la pluma, por ejemplo, su referencia a Chi-

12 El Tiempo de México, Febrero de 1886.

13 Parroquia de Nuestra Señora del Rosario. Partida de casamiento, año 1856, libro 3 fol. 1.

14 Iglesia parroquial de Santiago en Madrid, Partida de bautismo, año 1856, libro 14, fol. 195.

15 Hoja de Servicio de Miguel de la Torre Trassiera. Archivo de Historia y Cultura Militar 504/AGMSS S.T. $\mathrm{n}^{\mathrm{o}} 22088$ 
clana como "una de las más lindas poblaciones andaluzas..."16. En cuanto a Sevilla, ciudad que conocía bien ya que en ella pasó largas temporadas la distingue como "la ciudad reina del Guadalquivir"17. Recuerda la importancia de su legado cultural:

...En su archivo de Indias, en su biblioteca colombina, encuentra el historiador tesoro de datos que en vano buscaría en otras partes, la vieja ciudad reúne afanosa sus riquezas para demostrar a sus visitantes cuán digna fue de su fama y de su gloria...es la última vanidad del anciano que vive del recuerdo... ${ }^{18}$.

Preciosa es la descripción que, en el mismo artículo, hace de Cádiz:

...”y allá en el horizonte, blanca y bella como una ciudad de mármol acariciada por las olas, la antigua Gades, la plaza fuerte por excelencia y más fuerte aún por el espíritu de sus moradores... ${ }^{19}$.

Pero, a fin de cuentas, es la villa madrileña la que amplia sus horizontes culturales y le ofrece nuevas oportunidades al permitirle conocer el ambiente cultural que se vivía en la Corte y cultivar la amistad con los intelectuales del momento. Con toda seguridad, su admiración por Cecilia Böhl de Faber, 38 años mayor que ella, y su amistad con Gustavo Adolfo Bécquer, con quien mantendrá una interesante correspondencia, le reportó importantes beneficios intelectuales y acrecentó su formación humanista. Ya por estos años, Natalia reúne el perfil de la mujer del Romanticismo como sus coetáneas, Emilia Pardo Bazán, Gertrudis Gómez de Avellaneda, e igual que ellas, esconderá su condición de mujer bajo un seudónimo masculino, en su caso, el de Luis de Viana.

No debió ser fácil, para Natalia, la vida en Madrid, tan lejos de sus padres y de sus hermanos. De hecho viajará a Cádiz a menudo; tenemos constancia de que lo hizo en 1861 y en 1862 con ocasión del nacimiento de sus hijos, María ${ }^{20}$ y Fernando ${ }^{21}$. Aparece feliz tras su maternidad, su marido había ascendido a Teniente Coronel, su padre había incrementado su patrimonio y su familia, los Fernández de Castro, gozaba de gran prosperidad y prestigio en el mundo de los negocios como una de las más poderosas de la burguesía gaditana.

Pero esta felicidad se vería muy pronto enturbiada por una serie de desgracias familiares. En 1864, aparece en España con gran virulencia la crisis financiera que hizo estragos en la economía gaditana afectando a muchas empresas de la localidad, entre ellas, la de su familia, ”Ignacio Fernández de Castro y Cía. ”22, a la que perjudicó hasta el punto de verse obligado Ignacio a presentarse en quiebra. El disgusto de la familia

16 EL Tiempo de México, 12 de Mayo de 1866

17 El Tiempo de México, Septiembre de 1891.

18 El Tiempo de México, Marzo de 1890.

19 l Tiempo de México, Septiembre de 1891.

20 Partida de Bautismo de María Concepción de la Torre de Trasierra, Cádiz, Año 1861,libro 13 de bautismo, fol. 1 .

21 Partida de Bautismo de Fernando de la Torre de Trasierra, El Puerto de Santa María ,Año 1862, libro 134 de bautismos, fol. 237.

22 CÓZAR NAVARRO, $\mathrm{M}^{\mathrm{a}}$ del Carmen: op. cit. 
fue tremendo pues su madre, $\mathrm{M}^{\mathrm{a}}$ Concepción, andaba delicada de salud e Ignacio, su padre, era ya demasiado mayor y los negocios le superaban y no podía descansar en nadie, pues había perdido a su hijo, Rafael, y a su yerno, Manuel, que hubieran sido sus sucesores en los negocios. Por fortuna para ella, en Cádiz estaban sus hermanas Carmen y Josefa, que eran las que acompañaban a sus padres en estos momentos de tanta tribulación.

Para colmo de males y como las desgracias no vienen solas, en mitad de la quiebra del negocio familiar, en 1867, fallecían a la vez otros tres miembros de la familia, su madre, Concepción, su querido sobrino Domingo, hijo de su hermana Carmen, y, sobre todo, su marido, Miguel que la deja viuda en plena juventud.

De pronto un abismo se abre ante ella. Ciertamente, la vida se lo había puesto muy difícil. Se encuentra en Madrid, sola, viuda con 33 años y con tres hijos que sacar adelante, de 11, 6 y 5 años. A su difícil situación personal se añadía la inestabilidad que, en esos días, se vivía en España. El panorama político era desolador. La Revolución de 1868, con la caída de la monarquía isabelina, había traído consigo un clima de inseguridad que se había extendido y afectaaba a toda la sociedad española. Las guerras, carlista y de Cuba, la radicalidad de la Primera República y la explosión cantonal dificultaban los intentos de los gobiernos por normalizar la situación y crear un clima de estabilidad.

Natalia era consciente de que iniciaba una nueva etapa en su vida, en la que lo más importante para ella era la educación de sus hijos. Lejos de abatirse, se dispuso a participar de una manera activa en el mundo de las letras. La necesidad de allegar recursos para completar la que debió ser una exigua pensión de viudedad sería un poderoso acicate para el comienzo de su actividad literaria ya por los años setenta, según parece deducirse de la correspondencia mantenida con su amigo, Gustavo Adolfo Bécquer:

Mí apreciada amiga:

He comenzado a hojear la novela que ya conocía en parte y sin poderse determinar un día fijo creo que muy pronto la dejaré repasada. Respecto a la traducción creo que puedo pedir unos 900 reales. Las traducciones se pagan bastante mal.

Aprovecho con gusto esta nueva ocasión que se me ofrece de repetirle que estoy siempre a sus órdenes y que de ningún modo podría serme más agradable que disponiendo como le plazca de su verdadero amigo.

Gustavo Adolfo Bécquer

Hoy, 20 de noviembre de $1870^{23}$

No sabemos si sería esta la novela que Natalia presentó, unos años después, en los juegos florales de Matanzas, Cuba, titulada El Palacio, novela histórica publicada en 1891 y que, en la actualidad, se halla depositada en la Universidad de Harvard. Lo cierto es que, ya por esos años, Natalia se consideraba, además de madre, una escritora comprometida que disfrutaba con sus escritos.

23 Trascripción de una carta manuscrita escrita a Natalia por el poeta, Gustavo Adolfo Bécquer, que conserva los descendientes de Natalia Fernández de Castro 


\section{Crónica y vocación literaria}

Con la llegada al trono de Alfonso XII se inauguraba una etapa política en la que la estabilidad permitirá un desarrollo económico y social que redundará positivamente en su ánimo y, con toda probabilidad, en su producción literaria. El mantenimiento de su relación con su familia materna, que permanecía en México, además de sus dotes literarias, le facilitaría su entrada en el mundo laboral como colaboradora en la prensa mejicana, concretamente en El Tiempo, uno de los periódicos católicos más importantes y con más tirada de la capital de aquel país. Comprobamos, una vez más, como las relaciones entre España e Hispanoamérica no se interrumpieron tras la Independencia, sino que se recondujeron por diversos cauces. En este caso, la prensa fue un importante instrumento a través del cual se mantuvo el vínculo social y cultural entre España e Hispanoamérica.

Hay que tener en cuenta que Méjico iniciaba su andadura como nación con grandes dificultades. Desde el primer momento, los gobiernos mejicanos pretendieron fomentar la educación y preparar a los ciudadanos, llamados a constituir la nación. Había interés por conformar la conciencia de pública, y la prensa se ofrecía como un instrumento de difusión adecuado. En Méjico, sobre todo en provincias, la vida cultural se reducía a poca cosa, un concierto musical, una compañía itinerante de teatro, una esporádica velada literaria; por eso, la lectura de la prensa era un quehacer importante. Se puede decir que el periodismo fue el único tipo de publicación que llegó a todas las clases sociales y estimuló el desarrollo de la lectura ${ }^{24}$.

Consciente del poder de comunicación que tenían los periódicos ${ }^{25}$, las sociedades católicas locales, desde 1868, ejercieron poderosa influencia, estableciendo órganos de prensa en diversas localidades mejicanas, alguno de los cuales llegó a asumir un gran papel. Concretamente en Méjico, La Voz de México, El tiempo y El País serían los tres voceros más grandes de las corrientes conservadoras de la capital de la Republica.

En el caso de El Tiempo, su director y fundador, el licenciado Victoriano Agüe$\operatorname{ros}^{26}$, pregonó su defensa de los principios del conservadurismo a la par que defendió el catolicismo social, de tal suerte que sus periódicos fueron leídos y consumidos por casi toda la sociedad católica porfirista. Paladín de la causa española en México, a raíz de la fundación del periódico, en 1883, pedirá la colaboración de Natalia para dar las noticias de asuntos de España en la Sección extranjera.

La columna de Natalia se titularía "Cartas del Extranjero, España, Revista de la Semana”, firmando ella, como sabemos, con el seudónimo masculino de Luis de Viana. A partir de ese momento se convierte en portavoz de la sociedad española decimonóni-

24 PINEDA SOTO, Adriana : La prensa pro cultural de Michoacán hacia finales del siglo XIX en Los estudios impresos en América latina. Siglo XIX y XX, 2003.

25 CORNEJO QUESADA, Carlos: Presencia e Imagen del periodismo femenino en el siglo XIX.htpp//www. apfacom.org/articulos_pdf/las mujeres_periodistas_pdf, 2008.

26 Victoriano Agúeros, abogado, escritor colaborador en varios periódicos “El siglo XIX”, “La Iberia”, “La Ilustración Española y Americana”. Fundó el diario católico “El Tiempo” y “El tiempo Ilustrado” una de las primeras revistas ilustradas de México. Dirigió la biblioteca de autores mexicanos que reunió 78 volúmenes de lo más destacado de las letras mexicanas. Autor de "Ensayos de José”, artículos literarios y leyenda de Navidad. En CASTRO LEAL, Antonio: Semblanza de Académicos. Ediciones del centenario de la Academia Mexicana, México, 1975. 
ca y en la misma línea que las mujeres escritoras de su época, se manifiesta “como una mujer culta capaz de mantener una actividad literaria y manifestar una opinión política sobre los acontecimientos en curso “27.

En sus cartas, no se limitará a los temas que entonces eran considerados propios del bello sexo de la época, como religión o moda, sino que expondrá su opinión en cuestiones de actualidad, políticas, sociales y culturales, realizará crítica literaria y teatral, ejercerá de periodista taurina, recogerá la actualidad de la calle e incluso el humor y la anécdota formara parte de su repertorio periodístico. Su colaboración en el periódico no estuvo exenta de dificultades derivadas de la fuerte oposición ideológica y la actitud crítica que el Director del periódico mantuvo con el Gobierno de Porfirio, que le llevó a visitar la cárcel de Belén en diversas ocasiones e, incluso, a sufrir el cierre del periódico.

\section{Temas políticos y morales}

En su correspondencia de prensa, Natalia se muestra como una mujer conservadora, de profundas convicciones religiosas. En ocasiones, aprovechará la narración de una dulce y conmovedora historia para trasmitir una virtud cristiana ${ }^{28}$.

En marzo de 1886, relataba la historia de la señora de Dupuy de Lome, esposa de un diplomático español cuya generosidad con los más desafortunados de la sociedad llegó a poner en riesgo su propia vida:

“...La señora Dupuy de Lóme, esposa de un diplomático español agregado actualmente al ministerio de Estado, iba a entrar en su casa cuando vió una pobre mujer cubierta de harapos, que aunque desfallecida, sostenía entre sus brazos una criatura cadavérica...

La joven dama se sintió llena de compasión.....

....Suba vd., suba vd. Conmigo, necesita alimentarse en seguida..

... Pero aquella noche la señora de Dupuy de Lome se sintió enferma, y avisado el facultativo de la familia advirtió los primeros síntomas de unas anginas malignas epidémicas hoy en Madrid y de las que estaba atacada también la criatura que caritativamente había dado de mamar ${ }^{29}$. Los recursos de la ciencia fueron infructuosos para salvar a la señora de Dupuy y que murió dos días después" 30.

Muy caritativos y generosos fueron el Duque de Pastrana y su esposa cuya religiosidad les llevó a donar todo su patrimonio a la iglesia especialmente a los jesuitas.

“...católico ferviente, ampliaba su fortuna ya que no como sus mayores en fundaciones religiosas, redención de cautivos y suntuosos objetos para el sostenimiento del culto, en transformar parte de sus palacios en

27 ESPIGADO TOCINO; Gloria : “Mujeres y ciudadanía. Del antiguo régimen a la revolución liberal. Monografías sobre Historia de las mujeres en España. Debats., 2003.

28 El Tiempo de México: “La historia de la Sra, Dupuy “ 28 de Marzo de 1886.

29 Con una dulce y conmovedora historia intente trasmitir una virtud cristiana, en este caso la caridad 30 El tiempo de México, 28 de marzo de 1886. 
centros de educación dirigidos por los Padres de la Compañía de Jesús, asilos para huérfanos a cargo de las Hermanas de la Caridad y cuanto en esta época de descreimiento y soberbia emancipación, consideraban necesario para sostener en el pueblo la antigua fe y la cristiana conformidad. Últimamente el duque y su amantísima compañera residían en su hermoso castillo cerca de Pan, donde la muerte la halló ejerciendo como siempre a manos llenas la caridad....

¿Por qué no ha de permitir el Señor que la raza de esos hombres se perpetué?

...El duque de Pastrana ha muerto sin hijos; es una rama más que cae seca de aquel árbol en otro tiempo tan vigoroso y floreciente"31.

Partidaria de la monarquía absoluta y defensora de las tradiciones nacionales ${ }^{32}$ refiere como la monarquía borbónica fue un elemento de unidad y estabilidad en dos momentos de convulsión política no muy lejanos para ella como fueron la Guerra de la Independencia y el Sexenio Revolucionario. De esta manera relataba la vuelta de Fernando VII, el Deseado, tras la Guerra de la Independencia:

“...el amor idolátrico de los españoles; aquel amor abnegado y magnánimo había reconquistado el trono para el hijo de sus reyes, y sobrio de demostraciones y palabras brillaba esplendido en la actitud; "33.

En la misma columna, más adelante, Natalia relata como la prematura muerte de Alfonso XII, acontecida en 1885, frustró las esperanzas del pueblo que empezaba a disfrutar de la prosperidad y estabilidad que el nuevo régimen les había proporcionado tras los difíciles momentos vividos durante el Sexenio Revolucionario. Nuestra periodista comenta como el nacimiento del nuevo vástago real, un varón, Alfonso XIII, tranquilizó a la sociedad y a la clase política y frustró las esperanzas que el partido carlista, de nuevo, había puesto en la sucesión al trono ${ }^{34}$.

En su columna, nuestra corresponsal defiende la unidad de España y pone de manifiesto la preocupación de los madrileños por "un conflicto con las provincias levantinas, particularmente con Cataluña;” y es que empezaba, ya, por esos años a despuntar con verdadera virulencia los llamados, en esa época, regionalismos. En su opinión:

“...estas tendencias son funestas y están muy influenciadas por las ideas socialistas ${ }^{35}$.

Y, más adelante, comenta:

"El regionalismo, como todas las cosas de este mundo ha tenido grandes apasionados y numerosos impugnadores. En el estado actual de la

\footnotetext{
31 Ibidem.

32 Está en la línea de Fernán Caballero,Queta Lozano y Carolina de Soto y Corro que defienden la religión, la monarquía y sobre todo la familia, en CARMONA GONZÁLEZ, Ángeles: op. Cit. p. 27.

33 El Tiempo de México, 21 de mayo de 1886.

34 El Tiempo de México, 26 de julio de 1886.

35 Ibidem.
} 
sociedad, semejantes tendencias son por demás funestas. Los catalanes, hombres de temple duro, de carácter obstinado, no han acabado de amalgamarse á la patria comun, cierto es que el núcleo de aquel pueblo laborioso solo piensa en sacar partido de sus esfuerzos, en colocar ventajosamente sus productos y en proporcionarse por estos honrados medios el bienestar de su hogar; pero tambien lo es, que una minoría turbulenta trabajada é influida por el socialismo que busca con preferencia sus adeptos en las comarcas industriales, levanta fieramente la cabeza cada vez que una medida general le da pretexto para alardear de sus instintos de independencia. Fueros y leyes independientes tenian (sic) todos los antiguos reinos convertidos hoy en provincias españolas y con igual razon(sic), como dice Núñez de Arce, podian (sic) invocarlas y reclamarlas. Pero solo en Cataluña se oyen de tiempo en tiempo clamores separatistas, espada de dos filos que tendria (sic) que herir á la vez el corazon (sic) de la patria y la porcion segregada.

...Cuando hoy se aspira al Estado humano de Blunchlit y á la lengua universal, entendemos es un retroceso sostener tales utopias. (sic) Todo el mundo es patria del hombre....

Lo cortés no quita á lo valiente. Entretanto, S.M. la Reina Doña Cristina recibia(sic) en su palacio con toda clase de atenciones y entregaba por su mano las insignias de la órden(sic) de Carlos III á D. Benito Malvehy, comerciante en géneros manufactureros del principado catalán, y prometía(sic)al Sr. Marin (sic) visitar su establecimiento de productos puramente catalanes..."36.

\section{Temas sociales}

Como se ha comentado, ella fue, primordialmente, cronista de la sociedad española, sobre todo de la de Madrid, ciudad en la que, como ocurría en Barcelona y Cádiz, la vida social era intensa y esplendorosa. Siente una gran admiración por la familia real y el mundo de la Corte. Conoce a los miembros de la alta sociedad, políticos, diplomáticos y aristocracia, estamento éste último que le fascina y sobre el que nos proporciona una gran información, a partir de la cual podríamos ilustrar un estudio de los principales linajes del siglo XIX ${ }^{37}$.

A lo largo del texto se refiere a las señoras de la nobleza con sus nombres y apellidos, como por ejemplo a Carmen Fernández de Córdova y Pérez de Barradas, hija de los duques de Medinaceli:

“¿No es verdad que se parece a su madre en la época en que sostenía con la bella duquesa de Alba una competencia de hermosura que no era posible decidir? ${ }^{38}$ Se parece hoy todavía muchisimo; supongo que su futuro será ese jovencito que la acompaña....

\section{Ibidem.}

37 MARRADES, Ma Isabel y PERINAT, Adolfo: Mujer, prensa y sociedad en España. 1800-1939, Madrid, Centro de investigaciones sociológicas, 1980, p. 139 En las grandes ciudades, Cádiz, Barcelona, Madrid con una vida social tan intensa estas clases sociales protagonizaban las crónicas de sociedad.

38 El Tiempo de México, 10 de junio de 1886. 
Aludía a Don Francisco Losada y de la Rivas:

“...hijo único de los condes de Valdelagrana, único heredero de la inmensa fortuna de su abuelo materno, el Marqués de Mudela...”39.

Distingue a la nobleza de sangre, la de viejo cuño, la de rancio abolengo, de aquella otra nueva nobleza creada por la Corona por su ascendiente económico. Así relata el próximo enlace de la condesa viuda de Villamantilla con Don Martín Larios ${ }^{40}$, comerciante malagueño que había acumulado una importante fortuna y que había sido promovido recientemente al estamento nobiliario:

"A la entrada de los jardines había un grupo de cuatro hombres de la mejor sociedad; uno de ellos parecía forastero, era en efecto diputado por la provincia del Norte, y conocía poco a Madrid; sus palabras lo demostraban.

-Hombre, me habían asegurado que en Madrid no había mujeres bonitas, y las estoy viendo por docenas... Decía a media voz fijándose en una elegantísima dama cubierta de encajes que bajaba en aquel momento de una victoria. ¿Quién es esa preciosa mujer?

-Oh! Es una de las reinas de los salones madrileños; la condesa viuda de Villa-Mantilla.

-¿Viuda, has dicho?

-Si amigo, pero llegas tarde, está próxima a contraer nuevo enlace con uno de nuestros príncipes de la industria, Don Martín Larios, tan opulento como caballero" ${ }^{4}$.

Sabía donde encontrar el protagonismo de la noticia, conocía los paseos, asistía a la ópera, al teatro, carreras de caballos, costumbres de la alta sociedad.

"En la feria de Sevilla que tanta concurrencia lleva a la hermosa capital andaluza ha llamado la atención un soberbio caballo de silla llamado “manchonelo" cuya arrogante belleza, finura de miembros y de bellísima piel, lo constituían en una verdadera joya para los inteligentes. Su dueño, D. Baltasar Hidalgo, rico propietario de Medina Sidonia, le había puesto el precio de 5.000 pesetas..."42.

Muy informada de la moda, cualquier evento le da motivo para hacer una descripción fantástica de los vestidos de las aristócratas; el lujo en el vestir de las señoras y jóvenes de la alta sociedad en las festividades religiosas, para asistir a los paseos y distracciones como los toros, carreras de caballos, exposiciones, y es aquí dónde su condición femenina la delata, la hace vulnerable hasta el punto que es este el único indicio que podemos tener de su verdadero sexo, celosamente oculto tras la identidad masculina que deliberadamente adopta.

39 Ibidem.

40 PAREJO BARRANCO, Antonio: Málaga y los Larios, Málaga, Editorial Arguval, 1990, pp. 19-25.

41 El Tiempo de México, op. cit.

42 El Tiempo de México, 2 de mayo de 1886. 
En la carta del 30 de abril de 1889 informaba de lo brillantes que habían sido las fiestas religiosas celebradas en la Capilla Real :

“... la augusta familia que desde sus habitaciones particulares se dirigía con palmas en la mano y rodeada de la Corte á la hermosa capilla. S.M. la reina regente, siempre de negro pero siempre admirablemente vestida, lucía un traje de moiré(sic) brochado de gran cola recogida con la mayor elegancia...El traje de la infanta Doña Isabel era de raso gris y terciopelo verde, pero uno de esos verdes indefinibles de matiz tan bello como extraño, de los que la moda actual tiene el privilegio y la especialidad.

El conjunto de aquel hermoso traje, la combinación de los paños y colores era una joya de arte y de buen gusto, real y verdaderamente digna de admiracion(sic). Llevaba S.A. mantilla blanca, flores en la cabeza y magnífico aderezo de brillantes y esmeraldas. La infanta $D^{a}$. Eulalia iba de blanco; el vestido de riquísimo brocado y de un corte perfecto, la mantilla blanca, bien ceñida a su busto elegante, los cabellos rubios adornados de estrellas de brillantes, los brazos cubiertos de magníficos brazaletes. Veinte damas de las más distinguidas de la córte, (sic) acompañaban á S.M.A.A. RR.... La duquesa de Alba era un encanto y atraía todas las miradas. Su traje era blanco, pompadour, (sic) cuajado de piedras preciosas; diadema muy alta de magníficos brillantes; belete(sic) de riquísimos encajes. Sería interminable detallar las maravillas de lujo y de buen gusto lucidas por las veinte damas de la córte(sic) que rodeaban á S.M. y A.A. y por las señoras del cuerpo diplomático que se agrupaban en la tribuna. Era un cuadro digno del pincel de Fortuna" ${ }^{3}$.

La fascinación que siente por la aristocracia no le impide denunciar el derroche a que había llegado esta clase social caracterizada en el pasado, según Natalia, por su austeridad. En su opinión, en esta pérdida de valores ha tenido mucho que ver la imitación de las costumbres francesas: seducción por las joyas, por los viajes de verano, por el juego:

"Así como así, habrá alguna mujer que lo esté con su guarda-joyas, aunque un marido opulento y galante se lo aumente todos los días. Siempre le quedará algo que desear, siempre envidiará algo que no está a sus alcances. Hace algunos años, señoras de la más alta distinción pasaban perfectamente sin joya alguna o con sencillos diamantes que no se renovaban jamás, hoy el abuso en este punto va siendo tan costoso y absurdo, como el que hacia disolver sus perlas en vinagre, o pulverizarlas para adornar los manjares de sus mesas a las matronas y al pueblo romano"...

Y más adelante continua:

“-¿Y qué se habla de expediciones veraniegas? Mucho; por de pronto la familia real parece que irá al Norte, acaso a Comillas para que SS.AA. 
las infantitas tomen los baños de mar, después vendrán a la Granja donde terminarán la temporada. Los duques de Fernán Núñez y de Alba saldrán muy pronto para Bélgica donde les disponen su castillo de Dave; los duques de Sexto han marchado ya para París, donde sólo se aguardaba su presencia para la celebración del matrimonio del duque de Morny con la hija del general Guzmán Blanco; la duquesa viuda de Bailén se despide ya para San Sebastián....

- ¿Qué monomanía la de los viajes de verano!.... He aquí otro capricho ruinoso... ¿A dónde iremos a parar?”

Denuncia la extorsión que sufrió el conde de Xiquena, gobernador de Madrid, por querer acabar con el juego en Madrid:

“... El juego era escandaloso en Madrid. En todos los círculos se hablaba con más o menos reboso de pérdidas enormes que habían arruinado por completo a muchas conocidas familias ansiosas de salvar a sus hijos comprometidos; cuantos remedios se habían procurado poner a esta gangrena social de tan terribles resultados, habían sido de todo punto infructuosos, los dueños de tales garitos tenían fuerzas suficientes para pasar por encima de todas las leyes...." 44 .

Su crítica social alcanza también a la clase social más baja. En las páginas del diario deja constancia de la incultura popular, que se plasma en el habla vulgar, incorrecto y en la superstición de la que esta clase social hace gala. Llega incluso a contraponer estos dos mundos sociales, el de la nobleza y el del pueblo llano.

Cronista de la sociedad madrileña, condena los atentados terroristas. Así, a raíz de un atentado acaecido en Madrid escribe:

"Sabía acaso el miserable quien o quienes iban a ser las víctimas de su vil y cobarde acción? ¿Latía su corazón más aprisa al considerar que aquellas materias explosivas que encerraba en un cirio, causarían en aquel día desgracias sin cuento; que tal vez muchos padres de familia dejarían abandonado su hogar, huérfanos sus hijos de todo amparo, desvalidos en el mundo, en virtud de unas leyes que se atreven a llamar liberticidas o igualitarias, indispensables para la marcha progresiva del género humano?"45.

La denuncia social del maltrato a la infancia también aparece en sus cartas :

"Unos padres, desnaturalizados, dos monstruos de cobardía y de crueldad atormentan durante un año a su hija, niña de seis años, de un modo tan feroz que la desdichada criatura sucumbe cuando su pobre cuerpo era un montón informe de llagas y contusiones, cuando sus gritos y sus lloros habían decidido a los vecinos a dar parte aunque anónimamente a la autoridad. Lo brutal, lo espantoso de aquel atentado, hizo sublevar

44 Una extorsión en toda regla...

45 El Tiempo de México, Mayo de 1886. 
contra sus autores al popular barrio de Maravillas tan acostumbrado a las proezas de la navaja y a las colisiones sangrientas ${ }^{46}$. La indignación era tanta, que una doble fila de agentes de orden público no podía contener a la multitud resuelta a arrastrar a los que designaba después de haber presenciado la salida de su casa del cadáver de su hija... ${ }^{77}$.

\section{Temas culturales: teatro, literatura, música}

Informaba críticamente la cronista de los hechos culturales y literarios que acontecían en España. Se muestra conocedora de la obra de escritores como Novo y Colsón, Zola, Echegaray, Jacinto Verdaguer, Meléndez Pelayo, García Gutiérrez, López Bago escritor, éste último perteneciente al naturalismo radical e iniciador de la novela erótica.

Así comenta el estreno de la nueva obra de Echegaray "El Conde Lotario": "Como se ve el nuevo drama de Echegaray se parece a todos los demás que han brotado de su fecunda pluma. Brillante rasgos de genio dramático incuestionable, sabor antiguo como de ningún otro de nuestros autores modernos ha logrado obtener, pero escasa originalidad de caracteres y procedimientos, como si estuviese encariñado con un tipo único y característico del que le es imposible prescindir".... ${ }^{48}$

Los espacios de sociabilidad desempeñan un papel importante para esta dama tan observadora a la que llaman la atención las diferentes actitudes que adoptan las clases alta y baja. Así, contempla al público y describe las sensaciones que la obra de teatro despierta en los espectadores que, en ese momento, ocupaban la sala:

"Una nueva producción de Echegaray ha vuelto a apaciguar los ánimos; su anuncio llevó al Español por parte iguales, dos públicos totalmente diversos. El primero lo componían literatos críticos, periodistas, mujeres elegantes, jóvenes ¿ ???? Que nunca faltan a las solemnidades literarias aún cuando en realidad las artes y las letras les importen muy poco; en el segundo tomaban parte al lado de los numerosos amigos del poeta muchos empleados de escaso sueldo con sus mujeres e hijas; artesanos y obreros entusiastas por el teatro en general y por Echegaray en particular, como buenos hijos de Madrid. El primer público, ocupaba palcos y butacas; el segundo, las localidades altas; total un lleno completo. Observar estos dos públicos, era verdaderamente curioso. El culto, el elegante el que se preparaba a juzgar, afectaba ${ }^{49}$ una indiferencia absoluta; de cuando en cuando paseaba sus gemelos por la sala, y saludaba sonriendo a las conocidas; el popular, el que solo anelaba (sic) sentir, atento, silencioso, aguardaba por momentos el comienzo del drama, y en sus expresivos.............. en impaciencia.....Por fin, se alzó el telón y los bellos versos de Echegaray

\footnotetext{
46 Denuncia social del maltrato a la infancia. Ibidem.

47 El Tiempo de México, Mayo de 1886.

48 El Tiempo de México, Mayo de 1886.

49 Mostraba conocimiento del castellano.
} 
comenzaron a hacer su efecto. Poco a poco los dos públicos se amalgamaron, las impresiones se hicieron visibles, y primero en diálogos a media voz y luego en frases bien concretas, se manifestaron diferentes criterios. Como de costumbre para los ¿?? El drama era superior a todos los demás; para los otros Manantial que no se agota era acaso el más falso y el más inverosímil de cuantos ha escrito su ilustre autor".

En 1986, nos relata la impresión que le había causado una cantante de opera: "Adelina nada ha perdido de su expresiva y graciosa belleza; ha adquirido en cambio una elegancia "sui-generis" que tiene mucho de la distinción nativa de la española y de la seducción irresistible de la francesa. Entre los preciosos vestidos que lució durante su corta permanencia en Madrid, ninguno nos pareció tan bello como el que llevaba la noche de su tardor concierto. Era de raso blanco, el delantero cubierto de encajes magníficos, la cola inmensa, lisa, admirablemente cortada, guantes blancos muy largos; en el cuello una cinta de terciopelo blanco también sembrada de gruesos y soberbios brillantes; peinado sencillísimo pero en el que lucían como luceros unas cuantas piedras maravillosas... "50.

A raíz del estreno, en 1889, del estreno musical del maestro Serrano " $D$ a Juana la Loca” la bellísima referencias que hace, desde diversas ramas del arte,de la figura de la primogénita de los Reyes Católicos, denota su gran talla intelectual:

"Es verdad que la hija primogénita de nuestro Reyes Católicos es una figura tan conmovedora, que satura de melancólica poesía cuanto con ella se relaciona, haciendo vibrar el sentimiento de las multitudes, ya al contemplarla estática y asombrada ante el cadáver de su marido en el bello lienzo de Pradilla ${ }^{51}$, ya al escucharla divagar dolorosamente en el drama de Tamayo ${ }^{52}$, ó cuando la nota musical penetra hasta el fondo del alma, como en la obra del maestro Serrano. La Arkel ha hecho una Doña Juana incomparable, una creación (sic) de gran verdad histórica y de alto sentimiento dramático. Bella, apasionada, elegantísima, sus trajes son á la vez modelos de época y de gran distinción.

\section{Conclusiones}

Hora es ya de tratar de dar respuesta, a modo de conclusiones, a las cuestiones que planteamos al introducir el tema. ¿Fue Natalia un personaje femenino típico de su tiempo? ¿Quién fue la verdadera Natalia?

Los azarosos rasgos de su biografía, principalmente en torno a su matrimonio, la resuelta actitud con la que se enfrentó a su temprana viudez y la enérgica impronta de su estilo literario hacen presumir en Natalia una acusada personalidad, sin duda poco

50 El Tiempo de México, Marzo de 1886.

51 www/artehistoria.jcyl.es/genios/pintores/3046.htm.

52 www.es.wikipedia.org/wiki/manuel_tamayo y Baus. 
proclive a contemplar pasivamente el discurrir de su vida por los morigerados cauces previstos por la tradición para una dama de su posición. Su cumplida vocación literaria implica ya una tendencia a la rebelión, también experimentada por otras mujeres de su tiempo y condición más conocidas, a las que Natalia admiró, procurando su trato. En este sentido, creemos acertar al considerar a Natalia como un perfil femenino propio de su tiempo, el de la mujer cultivada cuyo espíritu, impulsado por la romántica brisa de la libertad, trata de escapar de las aguas restringidas en las que las costumbres lo tienen confinado, para navegar en el océano de las grandes cuestiones políticas y sociales propias de la emergente contemporaneidad.

Al examinar los textos, sin embargo, la escritora liberal que sugiere su biografía se metamorfosea ante nuestros ojos en dama que en ningún aspecto desentonaría en cualquier salón de la burguesía gaditana o de la aristocracia de la Corte. Es la Natalia, orgullosa de sus raíces, del poderío de su familia y del abolengo de su esposo, que para ostentar esta posición debe promover los valores tradicionales sobre los que se asienta. Y esta es, en su praxis, la verdadera Natalia. La otra, sólo es un sueño.

La impresión que nos deja la fugaz visión de esta mujer que hemos presentado es la de un personaje típico de la burguesía liberal española de la época, una aspiración de libertad y de progreso desdibujada por la fascinación que la tradición aristocrática de la periclitada sociedad estamental aún ejercía sobre una burguesía conformada por los ideales propios de la hidalguía originaria de gran parte se sus miembros, en los azarosos años que Natalia Fernández de Castro, una de las genuinas representantes de aquella nueva clase, le cupo vivir. 
